\title{
Dr. Muhammad Azhar Ali Khan (1934-2007): A Pioneer of IMANA
}

\section{Assalaamu alaykum}

Dear IMANA Members and JIMA Readers:

It is with great sadness that I write this eulogy for my dear brother and friend Dr. Khan (rahimahu Allah). At the same time, it is a great privilege for me to write this on behalf of the family of IMANA and FIMA.

Dr. Muhammad Azhar Ali Khan was not a founder of IMA (the precursor of IMANA) but certainly he was one of the pioneers who helped to sustain its growth and development. He was dedicated to the cause of IMANA and its mission, while also being the driving force for the formation of its "mother" organization, the Federation of Islamic Medical Associations (FIMA).
Dr. Khan graduated from King Edward Medical College, Lahore, Pakistan in 1959 and moved to the United States. After four years of postgraduate training, he moved to the United Kingdom and worked as a registrar in obstetrics and gynecology from 1966-1971. Dr. Khan returned to the United States and had further training in obstetrics and gynecology in Peoria, Illinois (1971-1973).

Dr. Khan established a busy private practice of obstetrics and gynecology in Peoria and joined the clinical faculty of the Obstetrics and Gynecology Department, University of Illinois, Peoria, until 1989. He then moved to Chicago as a clinical associate professor at the University of Illinois College of

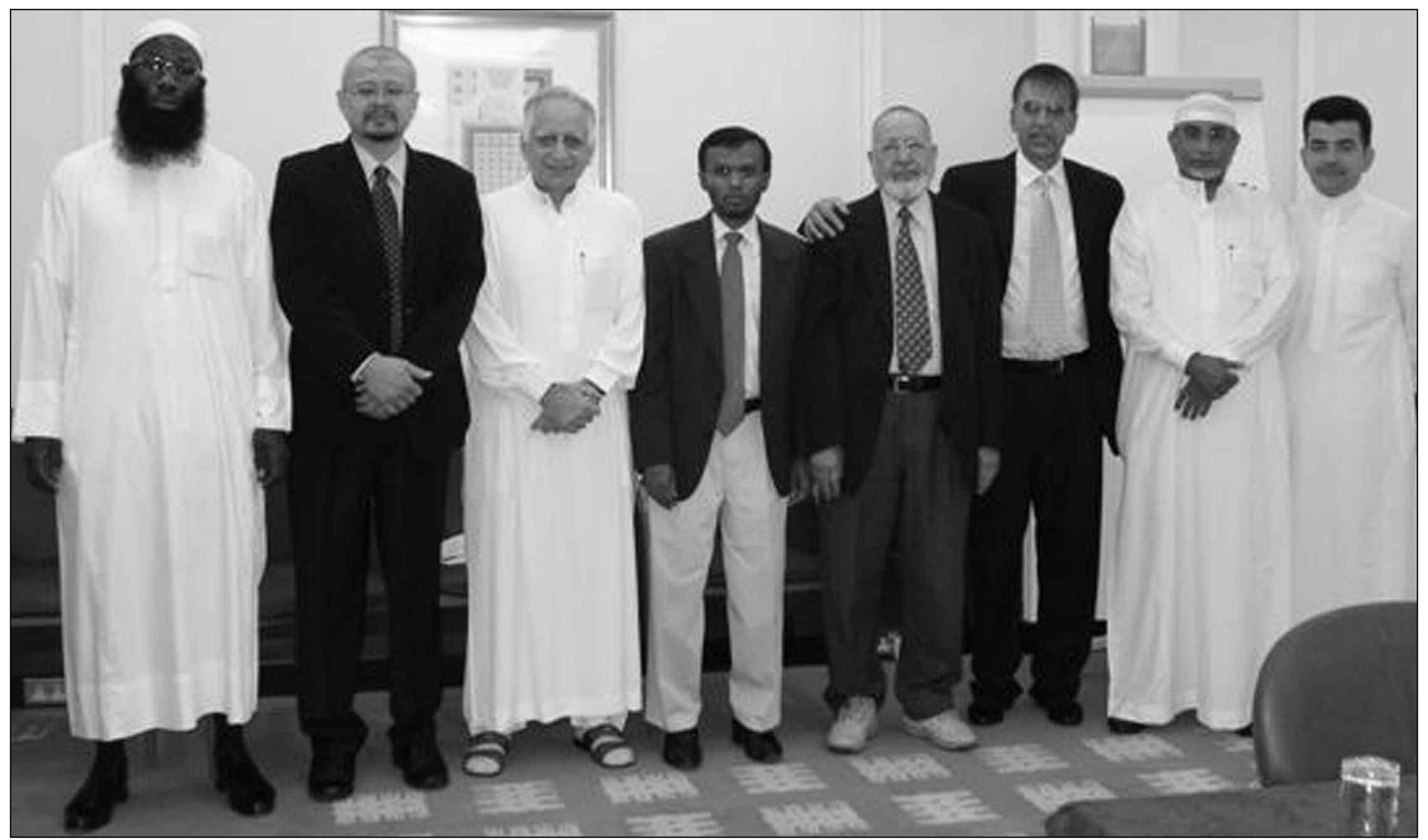

Dr. Khan (the fifth from the left) is pictured with other delegates at the recent conference in Jeddah on April 28-29, 2007. 
Medicine, Chicago. In 1993, he became an associate professor and a professor in 1998. He retired in 2000 as professor emeritus. During his tenure at the university, he held several positions in the different committees. The main ones among them were the Admissions and Continuing Medical Education (CME) Committees.

Dr. Khan was a member of many professional organizations, including the Chicago Medical Society, the American Association of Gynecologic Laparoscopists, and the American Fertility Society. He was a fellow of the American College of Surgeons as well as the American College of Obstetricians and Gynecologists. Dr. Khan had numerous publications and gave numerous presentations in scientific meetings, both nationally and internationally.

While on the faculty at the University of Illinois, he extended his activities to participate in other medical schools in different Muslim countries. During the years 1996-1999, he was a visiting professor in Tashkent States Second Medical Institute, Tashkent, Uzbekistan; in Muhimbili University College, Dar ulSalam, Tanzania; in the Islamic Hospital, University of Jordan, Amman, Jordan; and in the University of Sana'a, Yemen. He also served as an external examiner of Obstetrics and Gynecology for the MBBCh (MD) degree at the University of Sana'a, Yemen, and in the Jordan University of Science and Technology, Irbid, Jordan. Dr. Khan was appointed as vice-chairman of the University of Science and Technology, Sana'a, Yemen, during the years from 2000 to 2002.

In addition to his extensive professional involvement, Dr. Khan was very active in Islamic organizations. He was active not only in his local Muslim community but was also looking at the Muslim community at large. He joined IMA (IMANA) in 1976. From the beginning, he was interested in increasing the membership. Shortly thereafter, he became the chairman of the Membership Committee. He developed a membership directory for the first time. He also developed the first formal constitution and bylaws of IMA in 1982. He held several offices in the Executive Committee beginning in 1979 as a treasurer and became the president in the year 1983-1984. He also served on the Board of Regents and was its chairman in the year 1995-1996. He was the chairman of the Scientific and Education Committee from 1996 to 1999. In collaboration with the Jordan Medical Association and the Egyptian Medical Syndicate, he organized successful meetings in Amman, Jordan, in
1997 and in Cairo, Egypt, in 1999.

Although Dr. Khan was not directly involved in the CME Committee in the last few years, his goal was to have IMANA recognized as an accredited institution to sponsor CME programs. Dr. Khan initiated the process but, unfortunately, he could not complete the task.

When problems arose with the IMA headquarters operation in 2001, and IMA was in a period of turmoil, the Board of Regents at the time asked Dr. Khan to head a Headquarters Management Committee along with Drs. Nabil Haffar, Iltifat Alavi, and Ashraf Toor. They took charge of the headquarters office, steering IMA in the correct direction.

I do not remember exactly when I first met Dr. Khan but I know that we worked together on the Executive Committee of IMA beginning in 1981. I was then the treasurer, and Dr. Khan was the vice president. Since then, we worked closely together and became lifelong friends.

Dr. Khan was a member of the editorial board of the Journal of the Islamic Medical Association (JIMA) from 1980 to 1984 and 1998 to 2000 during my first tenure as the editor-in-chief of JIMA and again when I resumed that position in July 2005.

I helped Dr. Khan with revisions/amendments to the bylaws several times during the years and most recently along with Dr. Iltifat Alavi with the major revamp of the bylaws in 2003.

Dr. Khan's vision was universal and not limited to our nation. He envisioned the need of all committed Muslim physicians across the world to join their efforts in the service of humanity, their communities, and the Muslim Ummah. He worked to translate his vision into reality by the establishment of FIMA in 1981, even when the IMA of North America was still in its initial stages of growth. An accompanying tribute by current FIMA President Dr. Musa bin Mohammad Nordin describes his leading role and his achievements at FIMA. I am not going to repeat these, but I want to stress the tremendous work he accomplished in having FIMA gain consultant status by the United Nations Committee of Non-Governmental Organizations (NGOs)/Department of Economic and Social Affairs. I remember how excited he was (rahimahu Allah) when he called me with the news.

As part of Dr. Khan's involvement with FIMA, he and I, along with Dr. Aly Mishal, the president of Jordan's IMA, conceived the idea of publishing a FIMA yearbook. I was privileged to be chosen as the editor-

JIMA: Volume 39, 2007 - Page 104 
in-chief, and Drs. Khan and Mishal were named associate editors. Four yearbooks have been published so far in the years from 2002 to 2006.

Dr. Khan was recently invited by the Saudi Arabian General Investment Authority (SAGIA) and King Abdullah Foundation to organize a conference of Muslim scholars of different disciplines: medicine, science, technology, etc with the aim of establishing a global center of excellence for Muslim scholarship, research, and development in al-Madina alMunawarrah (Saudi Arabia). Dr. Khan organized and presided over that meeting in Jeddah, Saudi Arabia, April 28-29, 2007. The meeting was attended by key representatives from FIMA, engineers, information technology experts, and businessmen. Dr. Faroque Khan represented IMANA. It was a successful meeting. Plans were made for a follow-up conference with much wider participation in March 2008, when the project will be discussed at more depth. The name given to the proposed center is the Madina Knowledge Economy City. This was the last major accomplishment of Dr. Khan's.

In conjuction with this conference. Khan performed Umra, spent some time in the Prophet's city, visited with family members in Saudi Arabia and Dubai. He then visited his mother in Pakistan. On his way back to the United States on May 14, 2007, he peacefully passed away in Dubai airport waiting for his connecting flight. He was put to rest in Dubai on May 15, 2007. His family members and close friends attended the burial. It was quite befitting that his long career in the service of the Muslim community ended after this conference and that he was buried in Dubai, a modern hub connecting East and West. It is rather symbolic of his life's work and passion, combining religious Islamic duties with work to advance the Muslim community.

Dr. Khan was a devout Muslim, a family man, and a sincere friend. He was a man of vision. He was a physician dedicated to the improvement of healthcare provided by Muslim physicians and healthcare delivery in Muslim countries. He volunteered his time both when he was an active practitioner as well as in his retirement. I urge young IMANA members to emulate his devotion and perseverance and to continue on this path to achieve the lofty goals he set. May Allah bless his soul, grant him Jannat al-Firdus, bestow on him eternal peace and bliss, and give his loving family patience and perseverance

\section{Wassalam, \\ Hossam E. Fadel, MD, PhD, FACOG \\ Editor-in-chief, JIMA \\ Director of Maternal Fetal Medicine \\ University Hospital \\ Clinical Professor \\ Medical College of Georgia \\ Augusta, Georgia}

P.S. The IMANA website has created a message board where many IMANA members and friends have posted their reflections, and you can do so also. 